https://helda.helsinki.fi

\title{
Human noroviruses in the faeces of wild birds and rodents-new potential transmission routes
}

Summa, M.

2018-08

Summa , M , Henttonen , H \& Maunula , L 2018 , ' Human noroviruses in the faeces of wild birds and rodents-new potential transmission routes ' , Zoonoses and Public Health , vol. 65 , no. 5 , pp. 512-518 . https://doi.org/10.1111/zph.12461

http://hdl.handle.net/10138/326801

https://doi.org/10.1111/zph.12461

acceptedVersion

Downloaded from Helda, University of Helsinki institutional repository.

This is an electronic reprint of the original article.

This reprint may differ from the original in pagination and typographic detail.

Please cite the original version. 
1 Human Noroviruses in the Feces of Wild Birds and Rodents - New Potential

2 Transmission Routes

3

4 Maija Summa $^{1 *}$, Heikki Henttonen $^{2}$ and Leena Maunula ${ }^{1}$

5

$6{ }^{1}$ Department of Food Hygiene and Environmental Health, Faculty of Veterinary Medicine,

7 University of Helsinki, Finland

$8 \quad{ }^{2}$ Natural Resources Institute Finland, PO Box 2, FI-00790 Helsinki, Finland

9

10

11

12

13 *Corresponding author. Mailing address: Department of Food Hygiene and Environmental

14 Health, Faculty of Veterinary Medicine, PO Box 66, FI-00014 University of Helsinki, Finland.

15 Phone: +358-29-41-57175. E-mail: maija.summa@helsinki.fi

16

17 
Human noroviruses (HuNoVs) are one of the leading global causes of diarrheal diseases, and are transmitted mainly from person to person but also through contaminated food, water, and fomites. The possible zoonotic nature of NoVs has occasionally been discussed, though the viruses are generally considered to be host-species-specific. We investigated whether wild birds and rodents could serve as carriers of HuNoVs, thereby transmitting the virus to humans directly or indirectly by contaminating foods. All samples, 115 avian and 100 rat feces collected in springs 2009-2013 from dump sites, and 85 feces from yellow-necked mice trapped in late autumn 2008 and 2009 after the rodents entered human settlements due to the first night frosts, were screened for $\mathrm{HuNoV}$ using real-time reverse transcription-PCR. HuNoVs were detected in $31(27 \%)$ fecal samples of wild birds, in two (2\%) fecal samples of rats, and in no samples of mice. Most (25) of the positive bird samples and both rat samples contained genogroup II, and six positive bird samples contained genogroup I HuNoV. The avian species shedding feces containing HuNoVs were identified as gulls and crows using DNA barcoding. Our results show that wildlife, birds and rats in particular, is capable of spreading HuNoVs in the environment.

\section{Keywords}

Human norovirus, reverse transcription-PCR, transmission route, carrier animal

\section{Bullet points}

37 We studied if wild birds and rodents could carry human noroviruses, and thereby transmit the virus to humans directly or indirectly by contaminating foods. samples of rats, and in no samples of mice. 
41 The bird species shedding feces containing human noroviruses were identified as gulls and 42 crows.

43 
Human noroviruses (HuNoVs) are globally one of the major causes of acute diarrhoeal diseases in all age groups, as summarized in a recent review (Mathijs et al. 2012). Virus transmission mostly occurs from person to person via the fecal-oral route, but also commonly via contaminated food, water, or surfaces. A HuNoV infection usually causes strong symptoms, such as nausea, vomiting, and diarrhoea, which can appear within 12-48 hours of virus ingestion and disappear within 1-3 days. NoVs, members of the Caliciviridae family, are genetically diverse and classified into seven genogroups (Vinjé 2015), with HuNoVs belonging to genogroups I, II, and IV (Zheng et al. 2006). The most common HuNoVs, which also spread from person to person the easiest, belong to genogroup II.

NoVs are generally regarded host-species-specific, but the option of their zoonotic nature has been discussed (Bank-Wolf et al. 2010, Mathijs et al. 2012, Mattison et al. 2007, Mesquita et al. 2010, Scipioni et al. 2008, Wang et al. 2005, Wilhelm et al. 2015). The known animal NoVs in cattle, sheep, and mice (genogroups GIII and GV, respectively) differ considerably from human strains (Mathijs et al. 2012, Scipioni et al. 2008, Wolf et al. 2009). However, certain genogroup II NoVs in pigs closely resembled HuNoVs, raising debate about animal reservoirs and new recombinants (Wang et al. 2005, L'Homme et al. 2009). Mattison et al. (2007) have detected GII.4-like HuNoVs in swine and cattle feces and Summa et al. (2012) detected GII.4 and GII.12 HuNoVs in the feces of pet dogs. Caddy et al. (2015) have shown some evidence of HuNoVs occurring in dogs, and genogroup IV NoVs genetically resembling those found in dogs and lions have been detected in humans (Martella et al. 2007, Martella et al. 2008, Mesquita et al. 2010). All these findings point to the possibility of species-to-species transmission of NoVs. 
67 Wildlife is known to serve as a source of many zoonotic pathogens such as salmonella and rabies (Kruse et al. 2004). Rats and other small rodents are commonly found to spread various human diseases, such as salmonella and plague, but can also carry hepatitis E and hanta viruses (Kosoy et al. 2015, Leibler et al. 2016, Vaheri et al. 2013). Furthermore, wild birds reportedly transmit at least salmonella, mycobacteria, West Nile Virus, and Influenza viruses to humans (Tsiodras et al. 2008). The birds can also serve as reservoirs for many foodborne pathogens such as Listeria monocytogenes and Campylobacteria. Gulls and corvids (including crows and jackdaws) in particular are able to transmit numerous human pathogens (Tsiodras et al. 2008). So far, to our knowledge, HuNoVs have been detected in wild rodents only once (Wolf et al. 2013), and never in wild birds.

We investigated whether wild birds and rodents could carry HuNoVs and thereby transmit the virus, posing a direct infection risk to humans or a contamination risk to food and water.

\section{MATERIALS AND METHODS}

\subsection{Fecal samples}

A total of 115 avian fecal samples were collected during late winter (at the end of March) 2009 (50 samples), 2010 (30 samples), and 2011 (35 samples) from a dump site, which was used for household waste from the entire metropolitan area of Southern Finland. Bright days with new pure snow on the ground were chosen as the sample collection days. Fecal samples were collected aseptically from the untouched snow surface at sites with birds present and then frozen at $-20^{\circ} \mathrm{C}$. Gulls, crows, and jackdaws were the main bird species observed at the dump site.

Rat (Rattus norvegicus) samples comprised carcasses (8 samples) and droppings (92 samples). The samples were collected in late winter 2012 and 2013 from three dump sites in Southern 
Finland. The carcasses were found from different parts of the dump site and the droppings were mainly found near rat poison bait stations. Three mouse carcasses were also concurrently collected from the dump sites. Droppings and carcasses were frozen at $-20^{\circ} \mathrm{C}$. Carcasses were melted at room temperature and dissected to analyze the fecal samples collected from the gut.

All other mouse samples (85 samples, yellow-necked mouse Apodemus flavicollis) were obtained during studies on rodent-borne viral diseases by the Finnish Forest Research Institute, currently the Natural Resources Institute Finland. The mice were trapped in two localities in Southern Finland in late autumn 2008 and 2009 after the rodents entered human settlements due to the first night frosts. The mice were frozen at site, thawed at the later date, and their guts were dissected and frozen at $-20^{\circ} \mathrm{C}$. We excised the feces from the guts and used them for preparing a fecal suspension (see 2.2 detection of HuNoV genome).

\subsection{Detection of the HuNoV genome}

Fecal samples were diluted in phosphate-buffered saline (PBS) to a $10 \%$ suspension, and the viral RNA was extracted from the supernatant of the suspension using a QIAamp Viral RNA Mini kit (Qiagen GmbH, Hilden, Germany) according to instructions of the manufacturer. All samples were screened for $\mathrm{HuNoV}$ genogroups GI and GII using TaqMan real-time reverse transcription (RT)-PCR for polymerase-capsid junction as described by Summa et al. (2012) (incubation at $50{ }^{\circ} \mathrm{C}$ for $25 \mathrm{~min}$ for $\mathrm{RT}$, preheating at $95{ }^{\circ} \mathrm{C}$ for $15 \mathrm{~min}$, amplification of 50 cycles at $95{ }^{\circ} \mathrm{C}$ for $3 \mathrm{sec}$, at $54{ }^{\circ} \mathrm{C}$ for $25 \mathrm{sec}$, at $72{ }^{\circ} \mathrm{C}$ for $25 \mathrm{sec}$, and final incubation at $40{ }^{\circ} \mathrm{C}$ for $30 \mathrm{sec}$ ). In brief, the screening was performed using a QuantiTect Probe RT-PCR kit (Qiagen GmbH, Hilden, Germany) with primers and probes COG2R/QNIF2 and QNIFS for GII and QNIF4/QNIF3 and JJV1P for GI analysis. Each series in the RNA extraction and PCR run included blank reactions to rule out the possibility of cross-contamination between the 
samples. Theoretical limit of detection for the whole procedure was approximately 100 genome copies/ml in a $10 \%$ stool suspension.

\subsection{Sequencing and phylogenetic analysis}

The avian samples tested positive with PCR, a capsid portion of 377 nt (region C) was amplified using conventional RT-PCR with primers QNIF2 and G2SKR (Kojima et al. 2002) and a Qiagen One Step RT-PCR kit (Qiagen GmbH, Hilden, Germany). The nucleic acid sequences of the amplicons were determined at the DNA Sequencing Service, Institute of Biotechnology, University of Helsinki (www.biocenter.helsinki.fi/bi/dnagen/index.htm). The HuNoV genotypes were determined using a norovirus genotyping tool (www.rivm.nl). The sequences were aligned using the Clustal $\mathrm{W}$ software, and the phylogenetic tree was constructed by the neighbor-joining method with Kimura's correction using the NJplot software. GenBank accession numbers for sequences of avian samples are presented in the Results section.

\subsection{Definition of bird species}

Nucleic acid extraction was carried out on avian samples that tested positive for HuNoV, using $150 \mu \mathrm{l}$ of supernatant from the stool suspension using a MiniMag RNA extraction system (MM) and a NucliSens Magnetic Extraction Reagents kit (BioMerieux, France) according to the manufacturer's instructions. The nucleic acid was eluted in $70 \mu 1$ of elution buffer and then frozen at $-20^{\circ} \mathrm{C}$. For gene sequencing, the nucleic acid was amplified using conventional PCR (preheating at $94{ }^{\circ} \mathrm{C}$ for $10 \mathrm{~min}$, five cycles at $94{ }^{\circ} \mathrm{C}$ for $1 \mathrm{~min}$, at $45^{\circ} \mathrm{C}$ for $1.5 \mathrm{~min}$, and at 72 ${ }^{\circ} \mathrm{C}$ for $1.5 \mathrm{~min}$, amplification of 30 cycles at $94{ }^{\circ} \mathrm{C}$ for $1 \mathrm{~min}$, at $51^{\circ} \mathrm{C}$ for $1.5 \mathrm{~min}$, and at $72{ }^{\circ} \mathrm{C}$ for $1.5 \mathrm{~min}$ and final incubation at $72^{\circ} \mathrm{C}$ for $15 \mathrm{~min}$ ) with primers BirdR2 and BirdF1 (Hebert et al. 2004) and the Qiagen HotStarTaq Plus DNA Polymerase kit (Qiagen GmbH, Hilden, 
of each primer $(10 \mu \mathrm{M}), 0.5 \mu$ l DNA Polymerase (2.5 units), $13.5 \mu 1$ water, and $3 \mu 1$ of the sample. The nucleic acid sequences of the $750 \mathrm{bp}$ portions were determined at the DNA Sequencing Service. Bird species were determined using BLAST (U.S. National Library of Medicine, http://blast.ncbi.nlm.nih.gov).

\section{RESULTS}

Of the 115 avian fecal samples, 31 (27\%) tested positive for HuNoV, 25 samples for GII, and six samples for GI (Table 1). HuNoVs were found during each year that samples were collected. Positive results could be confirmed by repeating the real-time PCR for 12 samples and also by sequencing for six samples. Four samples contained genotype GII.4 and two contained GII.3 NoVs based on the capsid gene region (Table 2). The quantification cycle (Cq) values of all positive samples varied from 35 to 41 meaning allover weak positivity (see Table 2), and thus the PCR amplification of the longer PCR product for genotyping failed for most of the samples. All GI isolates remained without a genotype.

A phylogenetic tree (Figure 1) was formed using the 223 overlapping nucleic acid sequences from the capsid region $\mathrm{C}$ of the six HuNoV strains found in bird feces, 27 HuNoV GII strains in Genbank, and four GII strains found in dog feces (JF746890-JF746893, Summa et al. 2012). The sequences of isolates 7-09 and 10-09 were $98.7 \%$ and $99.1 \%$ identical at the nucleic acid level, respectively, and 100\% identical at the amino acid level, to the GII.4-2006b variant (EF126965) by the manual comparison of aligned sequences; the norovirus genotyping tool also recognized them as GII.4-2006b. The sequence of isolate 3-09 was closely related to GII.42006a variant (EF126964; 99.6\% identical in nucleic acids and 100\% in amino acids) and isolate 5-11 to the GII.4-2009 variant (JN595867; 98.7\% identical in nucleic acids and 100\% in amino acids). The sequences of isolates 1-10 and 9-11 were $93.6 \%$ and $96.9 \%$ identical in the nucleic acids and $97.3 \%$ and $95.9 \%$ in the amino acids to GII.3 strains U02030 and 
EU187437, respectively. Interestingly, the GII.4-2006b sequences of isolates 7-09 and 10-09 were also closely related to one of the isolates found in dog feces (JF746892, 98.2\% and 98.6\% identical in nucleic acids, respectively, and 98.6\% in amino acids) in Finland. The GII.4-2009 sequence of 5-11 was $97.3 \%$ identical in nucleic acids and $100 \%$ in amino acids to two isolates from dog feces (JF746890, JF746891) collected in 2009 and 2010.

Bird species could be identified in $10 \mathrm{HuNoV}$ positive fecal samples after partial nucleic acid sequence determination of their cytochrome c oxidase I (COI) genes (Table 2); the remaining 21 did not produce any PCR product. Eight samples were collected from gulls (Larus hyperboreus, Larus fuscus, and Larus argentatus) and two from crows (Corvus corone cornix).

Two (one from each year) out of the total of 100 fecal rat samples from dump sites tested weakly positive (Cq values of 38.30 and 35.90) for HuNoV GII with real-time PCR (Table 1), but the positive results could not be repeated. All 88 fecal samples from mice mainly trapped in human settlements tested negative for HuNoV.

\section{DISCUSSION}

We detected HuNoV genome in avian and murine fecal samples, showing that the viral genome can pass through the gastrointestinal tract of birds and rats. Consequently, wild birds and rodents may potentially carry $\mathrm{HuNoV}$ genomes from one place to another. All six partial NoV sequences detected in avian fecal samples were identical or nearly identical to previously published sequences from human samples and differed from avian or murine NoVs. During the NoV epidemic seasons of 2009 to 2011, HuNoV variants GII.4-2006b, GII.4-2006a, and genotype GII.3 circulated commonly in the human community in Finland (Hulkko et al. 2010, 2011, Jaakola et al. 2012) and were also present in avian fecal samples. The possibility of animal transmission of the $\mathrm{HuNoV}$ genome is also supported by previous studies, which 
observed HuNoVs in the feces of cattle, pigs, dogs, and a rat (Caddy et al. 2015, Mattison et al. 2007, Summa et al. 2012, Wolf et al. 2013).

But, how do birds become infected by HuNoVs and can these birds transmit NoVs to humans? Our avian samples were collected from a large dump site, which received all the household garbage from human settlements in the metropolitan area of Southern Finland until 2014. NoV infections, including asymptomatic ones, occur frequently in children younger than two years old (Pringle et al. 2015, Robilotti et al. 2015), who usually wear diapers. HuNoV remains infectious for several days unless inactivated e.g. using effective disinfectants (Weber et al. 2010), and therefore the virus is easily transferred to the dump site with discarded textiles, tissues, and diapers that may be contaminated with high amounts of the virus by infected persons. Consequently, the dumped rubbish among which the birds search for food may be highly contaminated with HuNoV during epidemic seasons. Interestingly, GII.4 and GII.3 NoVs, the genomes also present in our avian samples, dominated globally (67\% and 16\% 197 respectively) in children in 2004-2012 (Hoa Tran et al. 2013).

The food industry generally regards wild birds as noxious animals that spread numerous diseases (Tsiodras et al. 2008), and are therefore strictly controlled in primary food production and food premises. Birds are recognized to contaminate food and water with salmonella or campylobacter via their feces (Butterfield et al. 1983, Tsiodras et al. 2008), but our findings al. 2013, Weber et al. 2010), such as outdoor tables, handrails, etc., could also be a possible infection route from birds to humans. 
Several NoV outbreaks occurred in Finland during summer 2014, and they were shown to originate on a few beaches (Kauppinen et al. 2017). The source of water contamination was not clear, but the authors suspected that bathers and other beachgoers spread the virus. According to our results, birds carrying HuNoV could also be one, albeit minor, possibility. However, large seagull flocks could be a risk for human health, as they may contaminate public beaches and bodies of water which are used as a raw water source for household water.

Our study does not demonstrate that HuNoVs can replicate in the gastrointestinal tract of birds, as only viral genome was screened in the samples. According to our results, the viral genome load in the avian samples was low compared to human samples during acute infections. Norovirus is proposed to bind with carbohydrates of histo-blood group antigens (HBGAs) when interacting with a host cell (Green 2013). As reviewed by Shirato (2011), the FUT2 gene encodes HBGA carbohydrates in intestinal epithelial cells that are needed by HuNoV binding to the cells. According to Yamamoto et al. (2014), a large variety of organisms, including mice, rats, and dogs, carry the FUT2 gene. However, none of the bird species mentioned in the study (flycatcher, zebra finch, turkey, duck, chicken) have the gene. These findings and the low viral genome load in our samples suggests no or very limited replication in birds.

Fecal samples containing host intestinal cells have been used to identify host species (Lee et al. 2010). We succeeded in determining the bird species from 10 of our 31 avian fecal samples positive for HuNoV using PCR that was originally optimized for muscle tissues (Hebert et al. 2004). This non-invasive method worked well with fresh fecal samples of our study, but the quality of the host DNA in the fecal samples kept frozen may have deteriorated up to the point that the method could not specify the bird species in all samples. All identified bird species were gulls and crows, which are known to transmit numerous human pathogens (Tsiodras et al. 2008) and which were also usually observed during visits to dump site. 
Wolf et al. (2013) detected HuNoV in the intestinal content of a rat trapped in a sewer system. In addition to dump sites, sewer systems of urban areas are an important contamination source of $\mathrm{HuNoV}$ for rats. The low HuNoV genome load in our rat samples may partially be explained by the quality of our samples. The rat droppings were not fresh, so they could have been lying on the ground for an extended period. Because the droppings were collected near the rat poison bait stations, both feces and carcasses may have contained rat poison. We do not know if the rat poison could have damaged the virus particles in the gastrointestinal tract of rats.

Nearly all our mouse samples were from the species Apodemus flavicollis. Our sampling occurred late in autumn, when mice invading human settlements could pose a disease risk. Apodemus mice eat human and animal food and food waste while visiting human settlements, but they may not come in direct contact with $\mathrm{HuNoV}$ contaminated waste, e.g. diapers or sewage. The mice were also trapped outside the NoV epidemic season. As far as we know, no one, us included, has been able to detect HuNoVs in mouse samples (Leibler et al. 2016, Lõhmus et al. 2013).

Our results show that wild birds and possibly also rats are involved in the transmission of HuNoVs. At the very least these groups can mechanically carry the virus genome from the original source to a new site. Therefore, it would be important to keep in mind the option of birds as a contamination source when investigating NoV outbreaks caused by food or water. Determination of the replication capability of $\mathrm{HuNoV}$ in these new potential carrier animals requires more investigation, for example viral antibodies in blood or whole virus particles in feces should be searched for. 
255 We thank K. Söderberg, M. Rönnqvist, R. Åberg and S. Oristo for their assistance in sample 256 collection and handling, L. Kvist for her kind guidance in avian species determination, and C257 H. von Bonsdorff for his specialist advice during the conduction of this study. The work was 258 funded by the Academy of Finland (grant number 1122782), the Ministry of Agriculture and 259 Forestry (grant number 1884/312/2013), the Walter Ehrström Foundation, and the Finnish 260 Foundation of Veterinary Research.

Conflict of Interest: None.

\section{References}

Bank-Wolf B., König M., Thiel H-J. (2010). Zoonotic Aspects of Infection with Noroviruses and Sapoviruses. Veterinary Microbiology, 140, 204-212.

Butterfield J., Coulson J., Kearsey S., Monaghan P., McCoy J., Spain G. (1983). The Herring Gull Larus Argentatus as a Carrier of Salmonella. The Journal of Hygiene, 91, 429-436.

Caddy S., de Rougemont A., Emmot E., El-Attar L., Mitchell J., Hollinshead M., Belliot G., Brownlie J., Le Pendu J., Goodfellow I. (2015). Evidence for Human Norovirus Infection of Dogs in the United Kingdom. Journal of Clinical Microbiology, 53, 1873-1883.

Green K. (2013). Caliciviridae: The noroviruses. In: Knipe, D.M., Howley, P.M. (Ed.), Fields Virology, 6th edition (pp. 583-607). Philadelphia: Lippincott Williams \& Wilkins. 
Hoa Tran T., Trainor E., Nakagomi T., Cunliffe N., Nakagomi O. (2013). Molecular 276 Epidemiology of Noroviruses Associated with Acute Sporadic Gastroenteritis in Children: 277 Global Distribution of Genogroups, Genotypes and GII.4 Variants. Journal of Clinical 278 Virology, 56, 185-193.

279 Hulkko T., Lyytikäinen O., Kuusi M., Seppälä S., Ruutu P. (2010). Tartuntataudit Suomessa 280 1995-2009. National Institute for Health and Welfare. Report 17.

Hulkko T., Lyytikäinen O., Jaakola S., Kuusi M., Puumala J., Ruutu P. (2011). Tartuntataudit 282 Suomessa 2010. National Institute for Health and Welfare. Report 17.

Jaakola S., Lyytikäinen O., Rimhanen-Finne R., Salmenlinna S., Vuopio J., Roivainen M., Health and Welfare. Report 36.

Kauppinen A., Al-Hello H., Zacheus O., Kilponen J., Maunula L., Huusko S., Lappalainen M., Miettinen I., Blomqvist S. (2017). Increase in Outbreaks of Gastroenteritis Linked to Bathing Water in Finland in Summer 2014. Eurosurveillance, 22, pii=30470.

Kojima S., Kageyama T., Fukushi S., Hoshino F., Shinohara M., Uchida K. et al. (2002).

Genogroup-Specific PCR Primers for Detection of Norwalk-Like Viruses. Journal of

Virological Methods, 100, 107-114.

292

Kosoy M., Khlyap L., Cosson J-F., Morand S. (2015). Aboriginal and Invasive Rats of Genus 293 Rattus as Hosts of Infectious Agents. Vector-Borne and Zoonotic Diseases, 15, 3-12. 
296

297

298

299

300

301

302

303

304

305

306

307

308

309

310

311

312

313

314

315

316

317

Lee DH., Lee HJ., Lee YJ., Kang HM., Jeong OM., Kim MC., Kwon JS., Kwon JH., Kim CB., Lee JB., Park SY., Choi IS., Song CS. (2010). DNA Barcoding Techniques for Avian Influenza

Virus Surveillance in Migratory Bird Habitats. Journal of Wildlife Diseases, 46, 649-654.

Leibler J., Zakhour C., Gadhoke P., Gaeta J. (2016). Zoonotic and Vector-Borne Infections Among Urban Homeless and Marginalized People in the United States and Europe, 1990-2014. Vector-Borne and Zoonotic Diseases, 16, 435-444.

L'Homme Y., Sansregret R., Simard C. (2009). Broad Range RT-PCR Assays Targeting Human Noroviruses Also Detect Swine Noroviruses. Food Microbiology, 26, 552-555.

Lõhmus M., Janse I., van de Goot F., van Rotterdam B. (2013). Rodents as Potential Couriers for Bioterrorism Agents. Biosecurity and Bioterrorism: Biodefence Strategy, Practice, and Science, 11, 247-257.

Mathijs E., Stals A., Baert L., Botteldoorn N., Denayer S., Mauroy A., Scipioni A., Daube G., Dierick K., Herman L., van Coillie E., Uyttendaele M., Thiry E. (2012). A Review of Known and Hypothetical Transmission Routes for Noroviruses. Food and Environmental Virology, 4, 131-152.

Mattison K., Shukla A., Cook A., Pollari F., Friendship R., Kelton D. et al. (2007). Human Noroviruses in Swine and Cattle. Emerging Infectious Diseases, 13, 1184-1188.

Martella V., Campolo M., Lorusso E., Cavicchio P., Camero M., Bellacicco A. et al. (2007). Norovirus in Captive Lion Cub (Panthera leo). Emerging Infectious Diseases, 7, 1071-1073.

Martella V., Lorusso E., Decaro N., Elia G., Radogna A., D’Aramo M. et al. (2008). Detection and Molecular Characterization of a Canine Norovirus. Emerging Infectious Diseases, 8, 13061308. 
S., Kinnunen P., Maunula L. (2017). Contamination by Norovirus and Adenovirus on Environmental Virology, 9, 62-71.

Pringle K., Lopman B., Vega E., Vinje J., Parashar U., Hall A. (2015). Noroviruses: Epidemiology, Immunity and Prospects for Prevention. Future Microbiology, 10, 53-67.

Robilotti E., Deresinski S., Pinsky B. (2015). Norovirus. Clinical Microbiology Reviews, 28, 134-164.

Scipioni A., Mauroy A., Vinjé J., Thiry E. (2008). Animal noroviruses. The Veterinary Journal, $178,32-45$.

Shirato H. (2011). Norovirus and Histo-Blood Group Antigens. Japanese Journal of Infectious Diseases, 64, 95-103.

Summa M.., von Bonsdorff C-H., Maunula L. (2012). Pet dogs-A transmission route for human noroviruses? Journal of Clinical Virology, 53, 244-247. Associated with Wild Birds. Journal of Infection, 56, 83-98. Journal of Food Microbiology, 167, 346-352. 
339

Vaheri, A., Henttonen, H., Voutilainen, L., Mustonen, J., Vapalahti, O. (2013). Hantavirus Infections in Europe and Their Impact on Public Health. Reviews in Medical Virology, 23, 3549.

Vinjé J. (2015). Advances in Laboratory Methods for Detection and Typing of Norovirus. Journal of Clinical Microbiology, 53, 373-381.

Wang Q-H., Han M., Cheetham S., Souza M., Funk J., Saif L. (2005). Porcine Noroviruses Related to Human Noroviruses. Emerging Infectious Diseases, 11, 1874-1881.

Weber D., Rutala W., Miller M., Huslage K., Sickbert-Bennett E. (2010). Role of Hospital Surfaces in the Transmission of Emerging Health Care-Associated Pathogens: Norovirus, Clostridium Difficile, and Acinetobacter species. America Journal of Infection Control, 38, S25-S33.

Wilhelm B., Waddell L., Greig J., Rajic A., Houde A., McEwen S. (2015). A Scoping Reviewof the Evidence for Public Health Risks of Three Emerging Potentially Zoonotic Viruses: Hepatitis E virus, Norovirus, and Rotavirus. Preventive Veterinary Medicine, 119, 61-79.

Wolf S., Williamson W., Hewitt J., Lin J., Rivera-Aban M., Ball A. et al. (2009). Molecular Detection of Noroviruses in Sheep and Pigs in New Zealand Farms. Veterinary Microbiology, 133, 184-189.

Wolf S., Reetz J., Johne R., Heiberg A-C., Petri S., Kanig H., Ulrich R. (2013). The Simultaneous Occurrence of Human Norovirus and Hepatitis E Virus in a Norway Rat (Rattus Norvegicus). Archives of Virology, 158, 1575-1578.

Yamamoto F., Cid E., Yamamoto M., Saitou N., Bertranpetit J., Blancher A. (2014) An Integrative Evolution Theory of Histo-Blood Group ABO and Related Genes. Scientific Reports, 13, 4:6601. 
Zheng D-U., Ando T., Fankhauser R., Beard R., Glass R., Monroe S. (2006). Norovirus

363 Classification and Proposed Strain Nomenclature. Virology, 346, 312-323.

364

365 Figure legends

366 A phylogenetic tree was formed using the 220-bp sequence alignments consisting of a partial 367 capsid gene from six HuNoV GII strains found in avian fecal samples (marked "BIRD feces"), $36827 \mathrm{HuNoV}$ GII genotypes in GenBank and four GII strains found in canine fecal samples 369 (Summa et al. 2012, JF746890-JF746893, marked "DOG feces"). Norwalk GI.1 was added as 370 an outgroup. Phylogenetic analysis was performed with the neighbor-joining method using the

371 Clustal W software. Bootstrap values (1000 replicates) are shown on the branches. The scale 372 of the tree is indicated by the bar. 
Table 1. Fecal and carcass samples from birds, rats, and mice

\begin{tabular}{lccccc}
\hline & Total & HuNoV positives & & & \\
\cline { 3 - 6 } & number & GII & GI & total & $\%$ positive \\
\hline Bird & 115 & 25 & 6 & 31 & 27 \\
Rat & 100 & 2 & 0 & 2 & 2 \\
Mouse & 88 & 0 & 0 & 0 & 0 \\
\hline
\end{tabular}

Table 2. HuNoV-positive avian samples

\begin{tabular}{|c|c|c|c|c|c|}
\hline $\begin{array}{l}\text { Positive } \\
\text { samples }^{\text {a }}\end{array}$ & $\begin{array}{l}\text { HuNoV } \\
\text { GI / GII }\end{array}$ & Bird species & $\begin{array}{l}\text { Confirmed } \\
\text { (yes/no /Cq } \\
\text { value) }\end{array}$ & $\begin{array}{l}\text { NoV genotype } \\
\text { capsid region C }\end{array}$ & $\begin{array}{l}\text { Accession } \\
\text { no. in } \\
\text { Genbank }\end{array}$ \\
\hline $1-09$ & GII & Gull (Larus fuscus) & Y /38.68 & - & - \\
\hline $2-09$ & GII & Gull (Larus argentatus) & Y /39.02 & - & - \\
\hline 3-09 & GII & & Y /39.48 & GII.4 2006a & MF444290 \\
\hline 4-09 & GII & & Y /39.20 & - & - \\
\hline $5-09$ & GII & Crow (Corvus corone cornix) & Y /38.11 & - & - \\
\hline 6-09 & GII & & Y /40.44 & - & - \\
\hline 7-09 & GII & & Y /37.18 & GII.4 2006b & MF444291 \\
\hline 8-09 & GII & & Y /39.62 & - & - \\
\hline 9-09 & GII & Gull (Larus hyperboreus) & Y /39.34 & - & - \\
\hline $10-09$ & GII & & Y /38.64 & GII.4 2006b & MF444292 \\
\hline 11-09 & GII & & Y /39.85 & - & - \\
\hline $1-10$ & GII & Gull (Larus fuscus) & Y /39.63 & GII.3 & $--^{c}$ \\
\hline $2-10$ & GII & Gull (Larus hyperboreus) & $\mathrm{N} / 38.49$ & - & - \\
\hline $3-10$ & GII & Gull (Larus hyperboreus) & $\mathrm{N} / 39.53$ & - & - \\
\hline $4-10$ & GII & Gull (Larus fuscus) & $\mathrm{N} / 38.34$ & - & - \\
\hline $5-10$ & GI & & Y /39.18 & - & - \\
\hline $6-10$ & GI & & $\mathrm{N} / 39.48$ & - & - \\
\hline $7-10$ & GI & Gull (Larus hyperboreus) & Y /41.49 & - & - \\
\hline $8-10$ & GI & & $\mathrm{N} / 40.63$ & - & - \\
\hline $9-10$ & GI & & $\mathrm{N} / 40.24$ & - & - \\
\hline $1-11$ & GII & & $\mathrm{N} / 40.42$ & - & - \\
\hline $2-11$ & GII & & Y /38.91 & - & - \\
\hline $3-11$ & GII & & $\mathrm{N} / 39.47$ & - & - \\
\hline $4-11$ & GII & & $\mathrm{N} / 38.33$ & - & - \\
\hline $5-11$ & GII & & Y /38.16 & GII.4 2009 & MF444293 \\
\hline $6-11$ & GII & & N /38.64 & - & - \\
\hline $7-11$ & GII & & $\mathrm{N} / 38.36$ & - & - \\
\hline $8-11$ & GII & & $\mathrm{N} / 40.72$ & - & - \\
\hline $9-11$ & GII & Crow (Corvus corone cornix) & Y /35.87 & GII.3 & MF444294 \\
\hline $10-11$ & GII & & Y /38.29 & - & - \\
\hline $11-11$ & GI & & $\mathrm{N} / 39.71$ & - & - \\
\hline
\end{tabular}

a: running number of the sample- year of collection

b: positive PCR result on at least two occasions

c: nucleotide sequence too short for Genbank accession 
GI.1-Norwalk-M87661

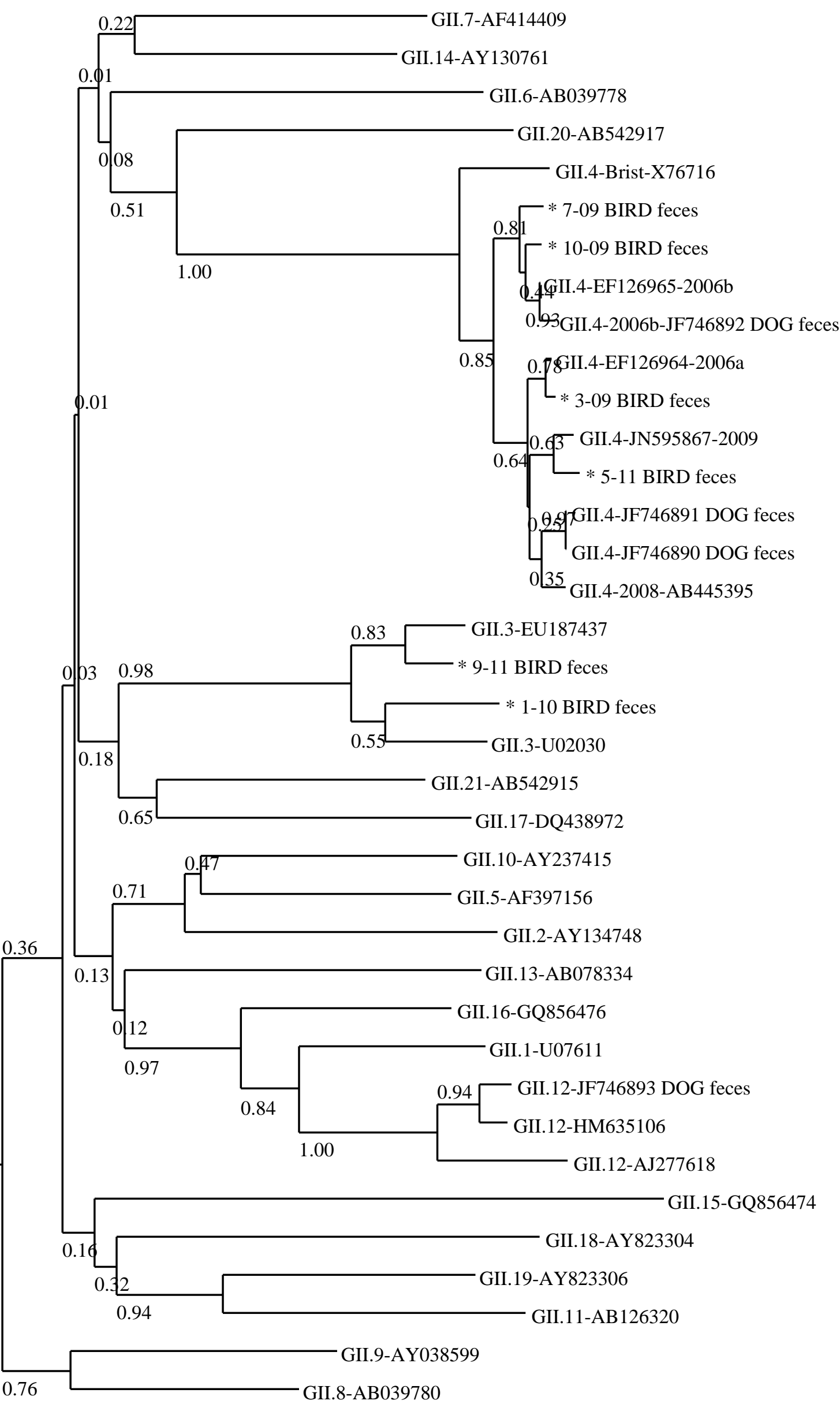

